\title{
Membangun Kesadaran Apokaliptik melalui sastra di Masa Pandemi
}

Abstrak

Artikel ini membahas kesadaran apokaliptik melalu sastra. Karya sastra yang digunakan untuk mengulik kesadaran tersebut adalah novel Inferno karya Dan Brown. Penulis menemukan bahwa melalui narasi dramatik tentang fakta-fakta sains di dalam novel Inferno dapat memberikan catatan alternatif dalam mengedukasi masyarakat mengenai bahaya virus COVID 19.

Kata kunci: Apokaliptik, Kesadaran, sastra, pandemi

\section{Pendahuluan}

Periode pandemi yang terjadi di seluruh dunia menciptakan situasi anomali di segala bidang, baik itu di dunia pendidikan, ekonomi politik, sosial-budaya, sampai di kehidupan religius, begitu pula dalam konstruksi infrastruktur (Arsyam, 2020). Peradaban bergeser ke situasi yang tidak menentu. Hal ini disebabkan publik dan kewenangan negara harus takluk pada standar protokol kesehatan. Masa adaptasi ini tentunya mengubah perilaku masyarakat, apakah itu di dunia pendidikan, pembelajaran agama/dakwah (Sainuddin, 2020) sampai di arena kebudayaan, bahkan dalam strategi penulisan skripsi (Wekke, 2020).

Namun, tidak dapat dipungkiri keberadaan pandemi ini ternyata mendapatkan respon yang beragam di tengah masyarakat dunia. Angka pasien COVID 19 di seluruh dunia telah mencapai angka 17, 9 juta jiwa dengan jumlah kematian mencapai 685 ribu jiwa, namun masih saja ada (kelompok) masyarakat yang menganggap pandemi COVID 19 sebagai intrik politik dan konspirasi. Terutama di media sosial, dakwah dan edukasi dianggap memberikan pandangan yang paradoks. Di satu sisi informasi menjadi begitu terbuka, di sisi lain informasi keliru pun juga ikut merebak (Sainuddin, 2020). Oleh karenanya, dibutuhkan formulasi tertentu agar masyarakat percaya bahaya wabah ini.

\section{Pembahasan}

Sastra sendiri sebagai representasi pikiran masyarakat ternyata telah lama mengangkat tema-tema apokaliptik. Manusia, melalui imajinasinya, menyadari kelemahan dirinya sebagai makhluk yang belum banyak menguak rahasia alam. Namun, dengan daya adaptasi yang dimiliki, manusia mampu belajar untuk mengurai masalah, sekaligus menemukan solusi untuk melestarikan spesiesnya (Makmur. Z, 2020). Salah satu diantaranya yang menawarkan gagasan apokaliptik adalah novel Inferno karya Dan Brown. Inferno berusaha menepis teori-teori konspirasi mengenai politik kesehatan yang selama ini menyebar di tengah masyarakat.

Melalui sastra apokaliptik, upaya menyadarkan publik tentang bahaya wabah merupakan cara yang cukup jitu. Di dalam novel Inferno fakta-fakta mengenai bahaya pandemi ditampilkan dengan dramatik. Tokoh-tokoh yang melibatkan ahli simbolog, ahli sejarah, dan dokter ahli dari WHO bergelut dengan waktu yang terbilang sempit. Bahaya virus genom yang dianggap mampu membuat manusia yang mengidapnya menjadi mandul, sehingga tidak mampu membuat anak. 
Novel ini juga menggambarkan sulitnya para ahli membaca gen dari virus, sehingga digambarkan oleh novel untuk menemukan tipe virus dan membuat anti-virusnya seperti mencari jarum di jagad semesta galaksi bimasakti. Itu dapat menjawab pertanyaan mengapa virus tersebut membutuhkan masa 12 tahun untuk menemukan vaksin tersebut.

\section{Kesimpulan}

Membaca sastra dapat memberi kesadaran dan pemahaman bahaya pandemi COVID 19. Novel Inferno karya Dan Brown sudah membuktikan adanya pembelajaran penting dalam memahami situasi yang anomal. Ini

\section{Daftar Pustaka}

Arsyam, M. (2020). Changes in Community Attitudes and Their Participation in the CommunityBased Water Supply and Sanitation Program (PAMSIMAS) in Gowa Regency. https://doi.org/10.31219/osf.io/gk569

Makmur, Z. (2020). Paradoxical Relationship between Humans, the Environment, And Science in Final Destination (Movies). https://doi.org/10.31219/osf.io/ukr4q

Sainuddin, I. H. Dakwah di Era Sosial Media. https://doi.org/10.31219/osf.io/2jxny

Sainuddin, I. H. Transformasi Dakwah di Masa Pandemi Covid-19. https://doi.org/10.31219/osf.io/nakhy

Wekke, I. S. (2020). Penulisan Skrispi di Masa Pandemi. https://doi.org/10.31219/osf.io/cqemp 